\title{
The Effects of Explicit/Implicit Instruction and Feedback on the Development of Persian EFL Learners' Pragmatic Competence in Suggestion Structures
}

\author{
Azin Salemi \\ Islamic Azad University, Shahreza Branch, Iran \\ Email: Sazin70@yahoo.com \\ Mitra Rabiee \\ Islamic Azad University, Shahreza Branch, Iran \\ Saeed Ketabi \\ Islamic Azad University, Shahreza Branch, Iran
}

\begin{abstract}
To date, a number of studies have investigated the speech act of suggestion. However, most of these studies have focused on the production - a sociolinguistic perspective - rather than the acquisition of this speech act. The study reported in this article aimed to compare the effects of implicit versus explicit instruction and feedback in the development of pragmatic competence of Iranian EFL learners of English in terms of the speech act of suggestion. The participants of this study consisted of 100 intermediate EFL learners of English who were randomly assigned to four experimental groups and a control group. Each experimental group participated in two twenty-minute successive sessions. The first experimental group received explicit instruction and explicit feedbacks, the second experimental group received explicit instruction and implicit feedbacks and the remaining two experimental groups were taught using implicit-explicit and implicit-implicit instruction and feedbacks, respectively. Data were collected using an immediate post-test as well as a delayed post-test which was administered a month after the post-test. Results of the study showed that the explicitexplicit method of instruction has a much better influence on Persian EFL learners. However, the results also demonstrated that the students tend to forget the instructed materials after four weeks. It follows from the results of this study that the development of pragmatic competence in terms of suggestion speech act is a complex process which proceeds in a non-linear fashion.
\end{abstract}

Index Terms - interlanguage pragmatics, explicit instruction, implicit instruction, explicit feedback, implicit feedback, focus on form, focus on forms, suggestion

\section{INTRODUCTION}

The study of pragmatics involves exploring the ability of language users to produce or comprehend language in a particular context. Stalnaker (1972) believes that pragmatics is "the study of linguistic acts and the contexts in which they are performed" (p. 383). The teaching of pragmatics, therefore, aims to facilitate "the learners' sense of being able to find socially appropriate language for the situations that they encounter" (Bardovi-Harlig \& Mahan-Taylor, 2003). According to Bardovi-Harlig (2001) and Kasper (1997), second language (L2) learners, regardless of their proficiency level, display a remarkably different pragmatic system than that of native speakers of that language - in terms of both production and comprehension of the language.

A number of studies (e.g., Boxer \& Pickering, 1995; Bouton, 1994; Kasper 1997; Bardovi-Harlig, 2001) have shown that EFL learners with high grammatical proficiency are not necessarily competent in pragmatic aspects of the FL. As Boxer \& Pickering (1995) rightly point out:

Grammatically advanced learners may not know how to use appropriate language in different situations and deviate from pragmatic norms of the target-language. One can find examples of pragmatic failure regarding L2 learners when they are involved in the communication acts. They may directly translate speech acts from their mother tongues into the FL when they are trying to get the intended meaning across. Unlike grammatical errors, pragmatic failures are often neglected by the teacher and sometimes are ascribed to some other causes, such as insolence. (p. 47)

Along the same line, Kasper (1997) and Bardovi-Harlig (2001) maintain that there are significant differences between FL learners and native-speakers with regards to their understanding as well as production of a given speech act. Taking this problem into account, they emphasize the need for teaching pragmatics in both second and foreign language classrooms. Following this call for more investigative attempts, recent years have witnessed an enormous interest in the 
instruction of pragmatics to EFL and ESL learners (Kasper, 2001; Kasper \& Rose, 2002; Martinez-Flor, Usó \& Fernández, 2003; Rose \& Kasper, 2001). So far, a number of empirical studies have confirmed the positive effects of teaching various pragmatic features, such as discourse strategies, pragmatic routines, conversational implicature, politeness in requests, interactional norms, and various speech acts (e.g., Billmyer, 1990; Bouton, 1994; Eslami-Rasekh, Eslami-Rasekh, \& Fatahi, 2004; Kondo, 2001, 2004; Kubota, 1995; Liddicoat \& Crozet, 2001; Lyster, 1994; Olshtain \& Cohen, 1990; Rose \& Ng, 2001; Safont, 2003, 2004, 2005; Salazar, 2003; Trosborg, 2003; Wildner-Bassett, 1994; Wishnoff, 2000). The explicit treatment in such investigations has offered metapragmatic information by describing, explaining and discussing a target linguistic form, in comparison with no-instruction conditions or as compared to native-speaker baseline data. Some other studies have examined the influences of educational approaches to pragmatic enhancement, usually making comparisons between explicit and implicit types of instruction (House, 1996; Takahashi, 2001; Tateyama et al., 1997). In the majority of these studies, explicit instruction has proven more useful than implicit instruction.

Several studies have compared the way people understand and produce speech acts in their first and second languages (e.g., Koike, 1989, 1995 \& LePair, 1996). According to Kasper (2001) while there are many observational studies that document what learners produce without any particular intervention by the instructor, there are relatively few studies on the effect of teacher intervention in the acquisition of L2 pragmatic features - a lacuna that the present study is to cover.

Koike and Pearson (2005) claimed that raising learners' awareness of target language functions, or of speech acts and instructing learners how these features can change across different contexts can be accomplished without detailed explanations. In fact, as Koike and Pearson (2005) argue, by virtue of the many similarities among languages in terms of different speech acts, perhaps the only thing that requires careful attention are the ways in which native speakers of a language (in this case English) differ from those of other languages in terms of the realizations of those functions.

Closely related to our discussion is the notion of focus on form (and also focus on forms). According to Long (1991), whereas focus on forms aims to foster the acquisition of individual language items focus on form involves a meaningfocused activity in which attention to form is implicitly accomplished. In other words, as Long states, "focus on form overtly draws students' attention to linguistic elements as they arise incidentally in lessons whose overriding focus is on meaning or communication" (pp. 45-46). One may extend this line of argument and suggest that in order for pragmatic functions to be acquired learners' attention need to be directed to them either implicitly or explicitly.

Following Schmidt (1993) argument, in which the "noticing" and "focus on form" concepts are discussed in relation to processing pragmatic input, this study attempts to examine whether instructors can explicitly help learners to focus on pragmatic form through explanation, lists, and rules, or whether learners learn pragmatics more effectively through simple observation and experimenting with language in a communicative context. It also aims to investigate whether instructors can help learners to focus on pragmatic form through explicit or implicit feedback. Tolli and Schmidt's (2008) study examined feedback and concluded that it has an overall positive influence on self-efficacy and goal revision on the part of the students. Also, in previous studies (e.g., Takahashi, 2001 and Tateyama, 2001), it wasn't clear that to what extent, this knowledge is retained over time. Therefore, the current study contributes to the available body of research by comparing the effects of implicit versus explicit instruction and feedback on the development of pragmatic competence of Iranian EFL learners of English in terms of the speech act of suggestion.

Prior to introducing the research questions it is necessary to discuss the speech act of suggestion. Speech act research continues to show that using speech acts is a complex process. This complexity, however, "has not always been recognized in the teaching of speech acts or functions" (Koester, 2002, p. 168). According to McCarthy (1998), textbooks typically try to make real language simple to use and simplify complexity by providing a list of phrase-level options. For example, when learners are working on how to give advice, they may only be practicing a list of phrases such as: 'You should...', 'Why don't you...?', 'If I were you, I'd...', and 'You ought to...'. The basic problem with such lists of phrases, as Koester (2002) claims, is that they tend to disclaim the fact that they are appropriate in certain context.

Kasper (1996b) maintains that "one of the causes of learners' non-target-like pragmatic performance is the incomplete or misleading input provided by pedagogical materials" (p. 18). Presenting real, representative language to learners should be the basic concern of classroom instruction. However, classroom communications often "produce a limited range of speech acts, simplified openings and closings, a lack of politeness marking, and a limited range of discourse markers in the classroom discourse" (pp. 149-169). Therefore, appropriate and adequate input from teaching materials, especially ESL textbooks, becomes crucial in the development of ESL learners' pragmatic competence.

\section{RESEARCH QUESTIONS AND HYPOTHESES}

Considering the theoretical and empirical issues discussed so far, the following questions and their corresponding hypotheses were addressed in the present study. Note that, since in the literature there were no study in support or against the research questions posed in this study, null hypotheses were formulated:

1. How is speech act of suggestion learned more effectively by Iranian EFL learners? Using explicit or implicit instruction?

It was predicted that there is no statistically significant difference between explicit and implicit types of instruction 
regarding their effects on the use of English suggestions by Iranian EFL learners.

2. How is pragmatic information learned more effectively? Through explicit or implicit feedback, concerning Persian EFL learners' use of suggestions and suggestion responses?

It was predicted that there is no statistically significant difference between explicit and implicit feedback regarding the use of English suggestions by Persian EFL learners.

3. Can any effects from this pragmatic instruction be sustained in Persian EFL learners after four weeks?

There is no evidence that effects of pragmatic instructions could be sustained in Persian EFL learners after a fourweek no-instruction period.

\section{MethodOLOGY}

\section{A. Participants}

A group of 130 female students of a language institute in Esfahan studying at intermediate level were randomly selected. To make sure that their knowledge of English in terms of grammar, vocabulary and communication skills was relatively the same, an OPT (Oxford Placement Test) was administered and as a result 100 students were chosen as the participants of the study - four experimental groups and one control group with each group comprising twenty students. Those whose scores were $1 \mathrm{SD}$ above and below the mean were selected as the intermediate level. The students' age ranged between 17 and 25. All the students were divided into four experimental groups and a control group.

\section{B. Materials}

In this section we will describe (a) the teaching materials used; (b) the way conversations were chosen for the participants; and (c) the ways in which they helped the participants of the study. Teaching materials that were used in this study generally fall into three major categories:

1. Pre-instruction materials (i.e. Oxford Placement Test)

2. While-instruction materials (i.e. Handouts, Conversation Practice, Role-play)

3. Post-instruction materials (i.e. Immediate Post-test, Delayed Post-test)

1. Pre-instruction Materials

Pre-instruction materials, as the name suggests, are those materials that were introduced to the participants prior to getting any kind of instruction. The purpose of using such material was to measure learners' overall knowledge of English. For this part, an Oxford Placement Test (OPT) was used to select the students that best suited the purpose of this study.

Oxford Placement Test is one of the most frequently used placement tests in the field of language teaching, as it encompasses almost every aspect and all levels of language proficiency, ranging from elementary stages of language learning to intermediate levels. It was first designed by Dave Allan (1994) and several revised editions were published since after. This test has proven a useful tool to for teachers, researchers and academic institutes to evaluate students' proficiency level in English. This test includes everything needed for grading and placing the students into classes in the most reliable and efficient way possible.

2. While-instruction Materials

While-instruction materials are those that were presented by the teacher during the course of teaching and include mostly classroom activities like classroom drills and role-plays. Firstly, the students were given a handout including a single situational conversation followed by five awareness-raising questions that they had to practice with their teacher in order to choose the best answers possible. This conversation as well as all the other conversations in the present study took place in specific contexts that required the students to fully understand the situation before answering any of the complimentary questions. In other words, our participants had to understand how the interlocutors related to each other, status and also the place where the conversations had taken place, to mark the best answers possible. At the first level of complexity the students were asked about the place of conversations. However, as they moved forward to more complex levels, they were asked to choose the most appropriate relationship, status, etc., between the interlocutors, with regard to the context they were presented with. This was followed by two comprehension questions.

Secondly, students were asked to practice the conversation presented in their handouts with a fellow partner with each student taking the exchangeable role of the higher- or lower-status interlocutor in the conversation. This activity helped the learners to notice certain qualities of the speech act of suggestion like formality and politeness, and provide them with an opportunity to practice different types of suggestions.

Table 1. shows different types of suggestions with corresponding expressions that were used during this activity. 
TABLE 1.

DIFFERENT TYPES OF SUGGESTIONS USED FOR CLASSROOM ACTIVITIES

\begin{tabular}{|c|c|c|}
\hline TYPE & STRATEGY & EXAMPLE \\
\hline \multirow{4}{*}{ DIRECT } & Performative verb & $\begin{array}{l}\text { I suggest that you ... } \\
\text { I advise you to ... } \\
\text { I recommend that you ... }\end{array}$ \\
\hline & Noun of suggestion & My suggestion would be ... \\
\hline & Imperative & Try using ... \\
\hline & Negative imperative & Don't try to ... \\
\hline \multirow{5}{*}{$\begin{array}{l}\text { CONVENTIONALISED } \\
\text { FORMS }\end{array}$} & $\begin{array}{l}\text { Specific formulae } \\
\text { (interrogative forms) }\end{array}$ & $\begin{array}{l}\text { Why don't you...? } \\
\text { How about...? } \\
\text { What about...? } \\
\text { Have you thought about...? }\end{array}$ \\
\hline & Possibility/probability & $\begin{array}{l}\text { You can ... } \\
\text { You could ... } \\
\text { You may ... } \\
\text { You might ... }\end{array}$ \\
\hline & Should & You should ... \\
\hline & Need & You need to ... \\
\hline & Conditional & If I were you, I would ... \\
\hline \multirow[t]{2}{*}{ INDIRECT } & Impersonal & $\begin{array}{l}\text { One thing (that you can do) would be } \\
\text { Here's one possibility: ... } \\
\text { There are a number of options that } \\
\text { You ... } \\
\text { It would be helpful if you ... } \\
\text { It might be better to ... } \\
\text { A good idea would be '" It would be nice if ... }\end{array}$ \\
\hline & Hints & I've heard that ... \\
\hline
\end{tabular}

The last classroom activity introduced to the students during the teaching sessions was the role-play activity which was actually a more enhanced version of previous activity by engaging students more interactively and directing their attention on how to put their learning experience into a life-like situation.

3. Post-instruction Materials

The last part of this section is devoted to our post-instruction materials or the immediate and the delayed post-test that the students had to take to complete each of the two successive sessions. We will discuss the arrangement of teaching sessions in the next section.

Having the students complete all the tasks and participate in classroom activities is meaningless unless we measure the effectiveness of those methods at the end. For this purpose, two tests (immediate post-test and delayed post-test) were designed. They were basically the same in construction but different in terms of conversations involved and the multiple choice items. They were both designed in a way to concentrate on three situational conversations containing the speech act of suggestion followed by three awareness raising and two comprehension questions.

The students took the first test (immediate post-test) after completion of the second instructional session and the second test (delayed post-test) was administered four weeks later to see if they could recall any of the instructed materials; in other words, to measure the variable of retention. In the next section these materials will be reviewed in more detail.

\section{Procedure}

1. General Procedure for all Groups

This section focuses on describing how four different combinations of instruction and feedback could be implemented in a Persian EFL classroom in order to foster learners' pragmatic competence when making suggestions. Particularly, we used these four different methods to see to what extent every method could help the learners improve their knowledge of L2 pragmatic competence or specifically the speech act of suggestion.

As mentioned before, the participants were divided into four experimental groups and a control. Each group received different types of instruction and feedback called respectively as:

1. EG1: Explicit Teaching - Explicit Feedback Group (ETEFG)

2. EG2: Explicit Teaching - Implicit Feedback Group (ETIFG)

3. EG3: Implicit Teaching - Explicit Feedback Group (ITEFG)

4. EG4: Implicit Teaching - Implicit Feedback Group (ITIFG)

5. CG: Control Group

Generally speaking, there are three steps involved in each session namely, introductory, practicing and the interactive phases. At the beginning of each session students were introduced to the new materials using the explicit or implicit method (Introductory phase). Following that, they were asked to do various drills to help them have a better understanding of the instructed materials (Practicing Phase). And finally, they would have to practice what they had learned with their friends that made them even more comfortable using the pragmatically correct language (Interactive phase). The following section will have a closer look at each of these phases. 
2. Specific Procedure for each Group

2.1. EG1: Explicit Teaching - Explicit Feedback Group (ETEFG)

The first session started with (EG1: Explicit Teaching - Explicit Feedback Group) a five-minute warm up along with an explanation to the students that their scores in these two sessions would not be counted in their final exam. It was made clear that there was no reason for anxiety.

After this short warm-up, a printed copy of a conversation between two friends was given to each student so that they could follow the instructor more easily. The related grammar rules were also written on the blackboard for their reference.

This conversation was read by the instructor a few times by putting the emphasis on suggestion speech acts and was followed by an explicit explanation of the grammar rules involved. Then, the students were presented with awarenessraising questions to make sure that they had learned how to make suggestions in a friendly environment. They were also provided with different options for answering these questions in their handouts.

An explicit feedback was made whenever they were making mistakes and they received correction in no time. An example of this kind of corrective feedback is brought here for further clarification:

Teacher: Hear me out and make suggestions according to the stated problem.

Teacher: I'm so bored. I couldn't get enough sleep last night.

Student: why do you take a nap?

Teacher interrupts and immediately corrects the student's mistake by saying:

You should always use the negative form of do with this expression. So the correct form is:

Teacher: Why don't you take a nap?

Next, the students were given a chance to read the dialogues and practice it with their fellow partners.

After they were ready, a role-play activity was given and they were helped by the instructor whenever needed. The whole session took about twenty minutes to be completed.

The following session started with a slightly different warm up since all the students were familiar with what they would be presented with. The instructor started teaching as soon as all the students had a copy of the new dialogue. Everything in their handouts was almost the same except the social status of the interlocutors. This time students were put in a more formal situation than what they had been placed before. More formal expressions and linguistic forms of suggestion were written on the blackboard and the teacher started reading the dialogue several times while the students were listening and the instructor explicitly explained how to make suggestions in a more formal situation.

After that, the students were given some time to read the dialogue, they did the complimentary awareness raising activities and practiced it with a fellow partner. When ready, they were asked to come to the board and take the role of the characters in the dialogue. This session lasted about twenty minutes and the score of each student was collected by means of an immediate post-test. The same procedure was used for the remaining EGs except the treatment that was different for each group.

2.2. EG2: Explicit Teaching - Implicit Feedback Group (ETIFG)

For EG2: Explicit Teaching - Implicit Feedback Group, the instructor started teaching the same as EG1 (ETEF). A brief warm up was given and the handouts were distributed among the students. Different patterns of suggestion were written on the blackboard and the students were explicitly taught how to make suggestions. After listening to the conversation read by the teacher, the students could get the chance to practice it with their friends and participate in awareness raising activities. Then, a number of volunteer students were asked to come to the board and role-play the conversation for their classmates. However, during this session and the next session the instructor did not explicitly comment on the students' performance and their mistakes were implicitly corrected just by repeating the correct form of the speech act of suggestion. An example of this kind of feedback is given below to further clarify the point:

Teacher: What would you say if you were to help Mona with her problem?

Student: I would say, you should talk to your mother before consulting a psychologist.

The teacher repeated the student's sentence using the correct form of suggestion:

Teacher: Why don't you talk to your mother before consulting a psychologist?

As you see the type of feedback that the students received was of implicit rather than explicit. For the second session, the students went through the same while-instruction practices using a more socially distant conversation and their scores were collected by means of an immediate post-test.

2.3. EG3: Implicit Teaching - Explicit Feedback Group (ITEFG)

For EG3: Implicit Teaching - Explicit Feedback Group different kind of treatment was used, that is to say, Implicit Teaching - Explicit Feedback.

The first session started with a quick warm up. As soon as the student got their handouts, the instructor started reading while the students were all ears but this time, no explicit grammar was written on the blackboard and it was tried to convey the grammar rules by means of more repetitions and changing tone of the instructor. Then, the students were asked to participate in awareness-raising activities and role-plays while their mistakes were explicitly corrected by the teacher. This session lasted about twenty minutes.

The next session was the same as the previous session, aside from using a more socially distant conversation as the instructional material and went on for twenty minutes the same as previous session. Afterwards, the students' scores 
were collected using an immediate post-test.

2.4. EG4: Implicit Teaching - Implicit Feedback Group (ITIFG)

For the last part of this research's data collection, a complete implicit method was used. This experimental group received no overt explanation of the grammar rules and the feedbacks were made by mere repetitions. And finally, the student's scores were again collected by means of an immediate and a delayed post-test.

\subsection{CG: Control Group}

The twenty students that were assigned to this group received no treatments. However, this group took the same immediate and delayed post-tests and its scores were used as a means to learn about the other experimental groups' progress.

In the next two sections we will wrap up this chapter by giving much more attention to data collection and statistical methods used to analyze the collected data.

\section{DAta COLlection}

In this research a five-part data collection procedure was used through using four immediate post-tests and a delayed post-test, and each of which contributed to the result of this study in its own way.

Immediate post-tests comprised of fifteen multiple-choice questions which were given at the end of the second session for each experimental group after their exposure to a specific treatment. Students were left on their own for a four-week period. Then, a delayed post-test was given to see if the students had retained any of the instructed materials.

In the next section, the statistical methods involved in this study will be briefly discussed.

\section{RESUlTS}

\section{A. The Investigation of the First Null Hypothesis}

The first hypothesis stated that there is no difference between explicit and implicit instruction regarding English suggestions used by Persian EFL learners. After administering the immediate post-test and collecting the data the results were analyzed. Table 2. indicates the descriptive statistics for the immediate post-test and Figure 4.1 depicts the graphical representation of the means.

TABLE 2.

DESCRIPTIVE STATISTICS FOR THE IMMEDIATE POST-TEST REGARDING INSTRUCTION

\begin{tabular}{llllll}
\hline \multicolumn{1}{c}{ Group } & No. & Mean & SD & Min & Max \\
\hline Explicit Teaching & 20 & 11.40 & 1.774 & 8.00 & 14.50 \\
Implicit Teaching & 20 & 9.00 & 1.784 & 6.00 & 13.00 \\
Control & 20 & 7.40 & 2.393 & 4 & 12 \\
\hline
\end{tabular}

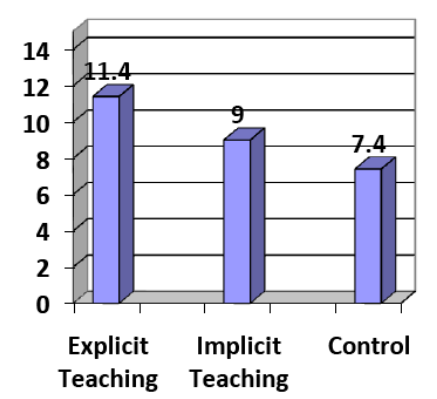

Figure 1. Graphical Representation of the Means for the Immediate Post-test

As it can be seen in the above table, the means of all three groups are different. In order to understand whether or not these differences are statistically significant, a one-way ANOVA was employed. Table 3. reveals the results of this ANOVA.

TABLE 3.

THE RESULTS OF THE ONE-WAY ANOVA FOR THE IMMEDIATE POST-TEST

\begin{tabular}{llllll}
\hline Source & SS & df & MS & F & Sig. \\
\hline Between Groups & 162.133 & 2 & 81.067 & 20.169 & .000 \\
Within Groups & 229.100 & 57 & 4.019 & & \\
Total & 391.233 & 59 & & & \\
\hline
\end{tabular}

As shown in Table 3., the result of the ANOVA analysis is significant $(F=20.169, \mathrm{p}<.000)$. In other words, our three groups did perform differently from each other. In order to find out where the exact place(s) of difference(s) is/are, a Scheffe post hoc test was run. Table 4.3 shows the results of this test. 
TABLE 4.

THE RESULTS OF SCHEFFE POST HOC TEST

\begin{tabular}{llll}
\hline groups & groups & Mean Difference & Sig. \\
\hline ETG & ITG & $2.400^{*}$ & .002 \\
& CG & $4.000^{*}$ & .000 \\
ITG & ETG & $-2.400^{*}$ & .002 \\
& CG & $1.600^{*}$ & .049 \\
CG & ETG & $-4.000^{*}$ & .000 \\
& ITG & $-1.600^{*}$ & .049 \\
\hline \multirow{4}{*}{ *. The mean difference is significant at the 0.05 level. } \\
& ETG= Explicit Teaching Group \\
& ITG= Implicit Teaching Group \\
\multicolumn{3}{c}{ CG = Control Group }
\end{tabular}

The results of the post hoc test indicate the following significant differences: a) between explicit teaching and the other two groups, b) between implicit teaching and the other two groups, and c) between the control group and the other two groups. In other words, explicit teaching group outperformed the other two groups, namely, implicit teaching group and the control group. Therefore, regarding what has been said in this section, the first hypothesis (differences between explicit teaching and implicit teaching) can safely be rejected, and it can be claimed that the type of teaching is effective in students' pragmatic performance regarding suggestions.

\section{B. The Investigation of the Second Null Hypothesis}

The second hypothesis stated that there is no difference between explicit and implicit feedback regarding English suggestion by Persian EFL learners. Here, once again, the results of the immediate post-test were analyzed with regard to explicit and implicit feedback. Table 5. shows the descriptive statistics of the results and Figure 2. shows the means graphically.

TABLE 5.

DESCRIPTIVE STATISTICS FOR THE IMMEDIATE POST-TEST REGARDING FEEDBACK

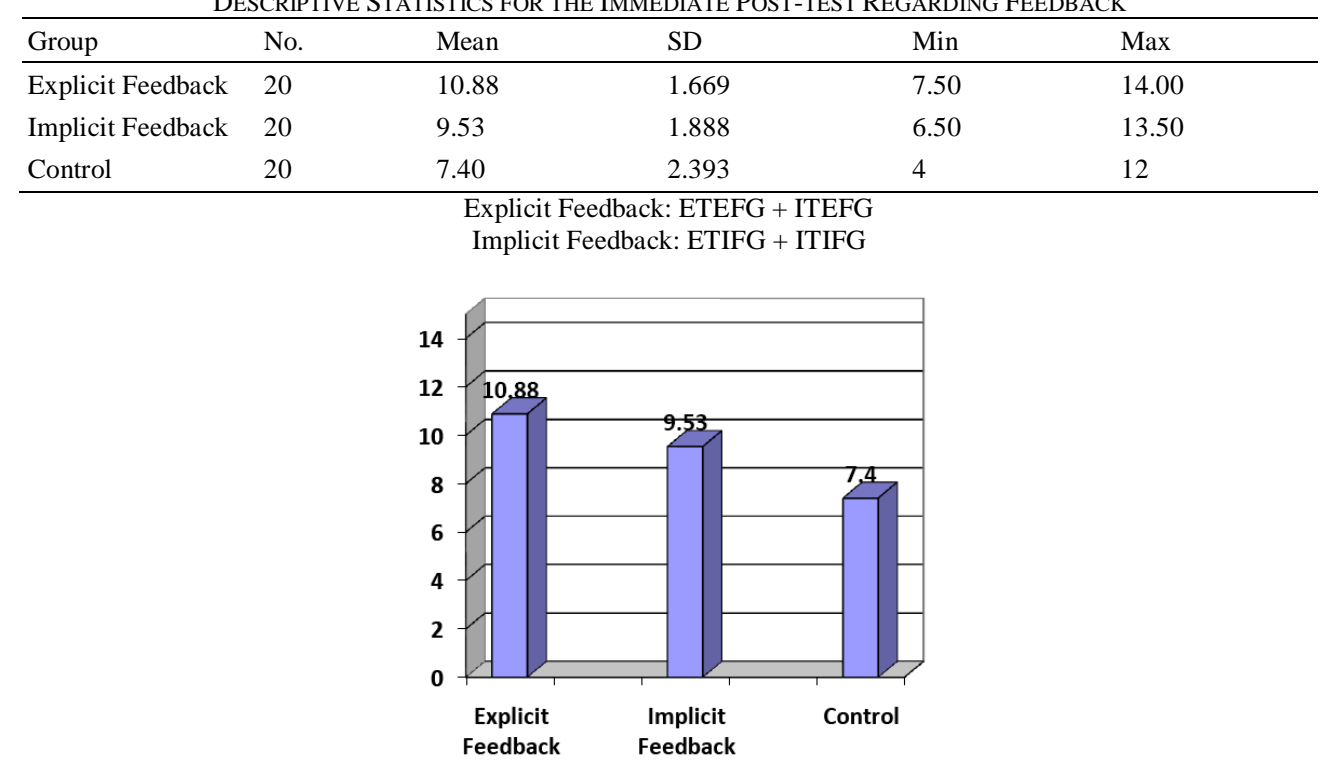

Figure 3. Graphical Representation of the Means for the Immediate Post-test

As it can be seen in the above table, the means of all three groups are different. In order to understand if these differences are statistically significant, another one-way ANOVA was employed. Table 6. depicts the results of this ANOVA.

TABLE 6.

THE RESULTS OF THE ONE-WAY ANOVA FOR THE IMMEDIATE POST-TEST

\begin{tabular}{llllll}
\hline Source & SS & df & MS & F & Sig. \\
\hline Between Groups & 122.758 & 2 & 61.379 & 15.246 & .000 \\
Within Groups & 229.475 & 57 & 4.026 & & \\
Total & 352.233 & 59 & & & \\
\hline
\end{tabular}

By referring to Table 6, one can understand that the three groups' performances were statistically significant. In order to locate the exact place(s) of difference(s), another Scheffe post hoc test was run. Table 4.6 presents the results of this 
test.

TABLE 7.

THE RESUlts OF SCHEFFE POST HOC TEST

\begin{tabular}{llll}
\hline Groups & groups & Mean Difference & Sig. \\
\hline ETG & ITG & 1.35 & .113 \\
& CG & $3.48^{*}$ & .000 \\
ITG & ETG & -1.35 & .113 \\
& CG & $2.13^{*}$ & .006 \\
CG & ETG & $-3.4^{8^{*}}$ & .000 \\
& ITG & $-2.13^{*}$ & .006 \\
\hline \multirow{4}{*}{ *. The mean difference is significant at the 0.05 level. } \\
& ETG= Explicit Feedback Group \\
& ITG= Implicit Feedback Group \\
\multicolumn{3}{c}{ CG= Control Group }
\end{tabular}

According to Table 7, the difference between the two experimental groups, namely, explicit feedback and implicit feedback, is not statistically significant $(\mathrm{p}=.113)$, but both of them performed better than the control group. Therefore, the second hypothesis retained; in other words, there is no difference between the performance of those who received the feedback explicitly and those who received it implicitly.

\section{The Investigation of the Third Null Hypothesis}

The third hypothesis stated that, "there is no evidence that effects of pragmatic instructions will be sustained in Persian EFL learners for four weeks". To test the validity of this hypothesis, a delayed post-test was administered four weeks after the last session. Table 8 reveals the descriptive statistics for this test and Figure 4. shows the graphical representation of the same means.

TABLE 8.

DESCRIPTIVE STATISTICS FOR THE DELAYED POST-TEST

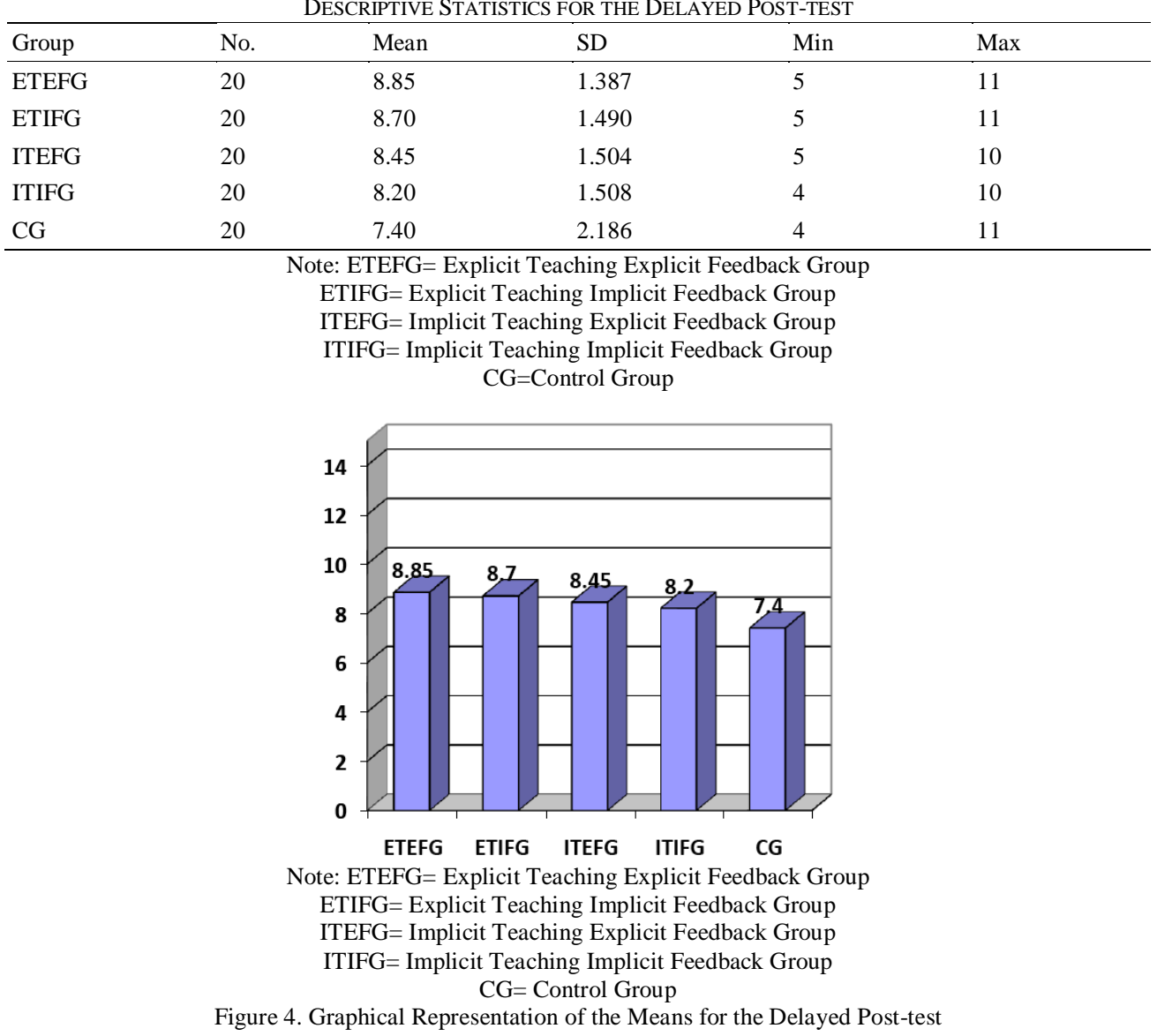

By looking at Table 8. and Figure 4., one can see some differences between the means of the five groups. To find out to what extent these differences are statistically significant, another one-way ANOVA was applied. Table 4.8 presents the results of this ANOVA. 
TABLE 9.

THE RESUlTS OF THE ONE-WAY ANOVA FOR THE DELAYED POST-TEST

\begin{tabular}{llllll}
\hline \multicolumn{5}{c}{ THE RESULTS OF THE ONE-WAY ANOVA FOR THE DELAYED POST-TEST } \\
\hline Source & SS & df & MS & F & Sig. \\
\hline Between Groups & 26.060 & 4 & 6.515 & 2.421 & .054 \\
Within Groups & 255.700 & 95 & 2.692 & & \\
Total & 281.760 & 99 & & & \\
\hline
\end{tabular}

The results of the one-way ANOVA, as can be seen in Table 9, shows a non-significant amount of $\mathrm{F}(\mathrm{F}=.421, \mathrm{p}<.54)$; therefore, the third hypothesis is retained. In other words, the learners in all four experimental groups and those in the control group performed almost the same, which means the effect of instruction almost faded away after a four-week no-instruction period. Next chapter will discuss the results in details.

\section{DISCUSSION}

For the purpose of evaluating the students' ability to produce appropriate suggestion speech acts in a conversational context, three null hypotheses were assumed at the very beginning of this study that are discussed here:

First Hypothesis: There is no difference between explicit and implicit instruction regarding English suggestion by Persian EFL learners.

Second Hypothesis: There is no difference between explicit and implicit feedback regarding English suggestion by Persian EFL learners.

Third Hypothesis: There is no evidence that effects of pragmatic instructions will be sustained in Persian EFL learners for four weeks.

\section{A. Addressing the First Hypothesis}

The first hypothesis stated that there is no difference between implicit and explicit instruction when we are dealing with teaching pragmatics to Persian EFL learners. To test this hypothesis, a descriptive analysis on the scores of immediate post-test taken by experimental groups was done. It showed that the mean of each experimental group regarding explicit/implicit instruction was different (Explicit Teaching=11.40, Implicit Teaching=9, Control Group=7.40) so our experimental groups actually preformed differently from each other and from the control group. Furthermore, the result of the ANOVA test $(F=20.169, p<.000)$ followed by the Scheffe Post hoc test supported the fact that implicit and explicit instructions have different effects on Persian EFL learners.

The results from the multiple choice sections suggest that the instruction in general had an effect on improvement of the learner's pragmatic knowledge to produce the suggestion speech acts. The explicit instruction appears to induce the best results for recognition of suggestion strategies on the multiple choice sections, making them more aware of pragmatic strategies and concepts. These findings support previous studies that indicate the benefits of explicit instruction for the acquisition of L2 pragmatics (Koike, 2003; Billmyer, 1990; Rose \& Ng Kwai-fun, 2001; Takahashi, 2001; Tateyama, 2001; Tateyama et al., 1997). However, it is worth mentioning that in the case of Koike's study there were also open-ended questions involved that we couldn't benefit from, considering the limited time of the present study. Koike (2003) believed that the implicit instruction along with negative feedbacks seems to be the most effective treatment when open-ended tasks are implemented.

On the other hand, explicit instruction in previous studies consisted of a wide range of activities that provided learners with meta-pragmatic information and/or raised their awareness of metapragmatic rules. Among them, an explanation and discussion of rules have prevailed (Bouton, 1994; Kubota, 1995; LoCastro, 1997; Olshtain \& Cohen, 1990; Safont, 2003, 2004, 2005; Trosborg, 2003; Yoshimi, 2001; Wishnoff, 2000). Following these approaches, the instructor of the present study dedicated two sessions teaching the appropriate usage of the target forms to each experimental group by explaining the relationships among the linguistic forms, function (i.e., suggestion), situations, and a factor of social distance. The outcome was that this study widened the scope of teachable speech acts by covering suggestions, since earlier studies have mostly demonstrated the positive effects of explicit instruction on requests, refusals, apologies, complaints, and compliments.

\section{B. Addressing the Second Hypothesis}

For the second hypothesis, another descriptive analysis was done on the immediate post-test scores of the participants. It was revealed that each experimental group performed differently from each other. In other words, the means were significantly different (Explicit Feedback=10.88, Implicit Feedback=9.53, Control Group=7.40). Similar to the first hypothesis, the same ANOVA and Scheffe Post hoc test was run to see if they confirmed the result of the descriptive analysis. However, It was shown that, despite the significant mean difference obtained from the descriptive analysis, this difference was not statistically acceptable $(\mathrm{p}=.113)$; therefore, the second hypothesis was clearly retained. In other words, there was no difference between the performance of those who received the feedback explicitly and those who received it implicitly.

However, these findings are in contrast with previous studies (Fukuya, Reeve, Gisi \& Christianson, 1998; Yoshimi 2001; Koike 2003) that gave extra credit to implicit corrective feedback over its explicit counterpart. Corrective 
feedback is an important condition that informs learners about their own output. This negative input may cause changes in learners' production leading them to develop their pragmatic competence. In spite of the minor difference regarding implicit and explicit feedbacks in the present study and the overall improvement of the students after receiving treatment, it is believed that incorporating feedback whether it be explicit or implicit in the EFL classroom is as essential as the input itself, to help learners develop their pragmatic competence.

\section{Addressing the Third Hypothesis}

To test the third hypothesis, as stated earlier, a delayed post-test was administered questioning the students the same suggestion rules they had already been introduced to. The descriptive analysis of the delayed post-test manifested that there was a slight alteration between means of each group. To see if this difference was significant statistically an ANOVA test was run similar to what had been done for testing other hypotheses. However, this time, the result showed that this difference was not significant $(\mathrm{F}=.421, \mathrm{p}<.54)$ and the third hypothesis remained in force. In other words, the students had not retained the instructed material over a four-week period.

The result of the third hypothesis is in harmony with two major studies (Koike, 2003; Martinez Flor, 2004) on suggestions. Their findings proved the non-effectiveness of either of the two types of instruction to maintain learners' long-term retention of their pragmatic knowledge. These findings and the results obtained from the delayed post-test of the present study could be attributable to the lack of proper input during the time spans. Further research seems necessary to look into the problem of retention when dealing with the acquisition of L2 pragmatic knowledge.

As mentioned before, one has to notice that the results of this study have indicated that learners learn pragmatic material, in this case, the complex speech act of suggestion, and develop their pragmatic competence more effectively when they get explicit instruction on the speech act of suggestion before doing exercises. The explicit instruction and feedback, more effectively, helped the learners read, understand, interpret, and select the most appropriate pragmatic choices of the immediate post-test.

These findings must be corroborated by further research. However, It appears that explicit instruction and feedback are effective in helping learners understand pragmatic elements and contexts by calling their attention to linguistic forms.

Thus, the explicit/implicit instruction and feedback may have varying effects on different areas of learners' competence. However, these findings should be interpreted by taking into account the limitations of the methodology employed in this study.

\section{CONCLUSIONS AND IMPLICATIONS}

According to Alcon (2001), the foreign language classroom has been regarded as a suitable environment for the acquisition of pragmatic competence; it is believed that employing similar methodologies in Persian EFL environments would be of benefit to foster learners' ability to make suggestions.

For this reason, four different combinations of instruction and feedback have been proposed, showing how such a methodology could be presented to learners and practiced through a series of awareness raising activities and opportunities for communicative practice. By means of such approaches, learners could be made aware of the fact that, in order to make an appropriate use of the different linguistic forms available for suggestions, several factors need to be considered, such as the situations where the suggestion is elicited, the contextual features involved in those situations, and the relationship between different participants that may appear in them.

It was shown that Persian EFL learners prefer explicit methods of instruction and feedback over other methods after receiving instruction and feedback in four different combinations. This might be due to the dominance of Persian language in Iran and not having English as a second way of communication in the actual community. So, the students are not in contact with English a lot. Most of the Asian countries like China or India prefer to be told the rights and wrongs of the second language they are learning, in this case English. And again for this reason, Persian EFL learners tend to forget instructed materials by the passage of time.

Having the illocutionary speech act of suggestion as a part of speech act theory at the center of attention, this study provided the learners with enough input to learn the proper usage of different types of suggestions in a variety of contexts. Additionally, this study sought to help the learners to better understand the status of each interlocutor within a context. It is believed that the students could make much better native-like responses when they were exposed to people with differing social statuses after getting explicit instruction and feedback; and for sure this is in support of the ideas behind the politeness and cultural adaptation theories.

This study investigated two types of instruction of speech act of suggestion which are explicit and implicit, demonstrating higher gains after the explicit instruction in comparison to implicit instruction. The results of this study, point to a positive improvement of the learner pragmatic competence after the planned instructional process. Moreover, the findings also showed that the instruction on L2 pragmatics is necessary even for learners of high language proficiency.

On the other hand, it was investigated that the pragmatic aspects of language are teachable, thus textbook writers and curriculum developers should pay more attention to this aspect of language which has been ignored so far and the instructors need to be familiarized with the importance of the instruction of pragmatic aspects of language especially 
explicit instruction. Moreover, it is useful for the instructors to go over previous SLA researches before choosing any specific methodology. They should also be aware of the fact that students in Persian environments tend to forget instructed materials in the long run. So, providing opportunities for better and more practices might be of a benefit to them.

\section{REFERENCES}

[1] Alcon, E. (2007). Incidental focus on form, noticing and vocabulary learning in EFL classroom. International Journal of English Studies, 7, 41-60.

[2] Bardovi-Harlig, K. (2001). Evaluating the empirical evidence: Grounds for instruction in pragmatics? In K. Rose \& G. Kasper (Eds.), Pragmatics in language teaching (pp. 13-32). Cambridge: Cambridge University Press.

[3] Bardovi-Harlig, K., \& Mahan-Taylor, R. (2003). Teaching pragmatics. Washington, DC: United States Department of State.

[4] Billmyer, K. (1990). I really like your lifestyle: ESL learners learning how to compliment. Penn Working Papers in Educational Linguistics, 6(2), 31-48.

[5] Bouton, L. F. (1994a). Can NNS skill in interpreting implicatures in American English be improved through explicit instruction? A pilot study. In L. F. Bouton \& Y. Kachru (Eds.), Pragmatics and language learning, (Vol 5, pp. 88-109). University of Illinois, Urbana-Champaign: Division of English as an International Language.

[6] Bouton, L. F. (1994b). Conversational implicature in a second language: Learned slowly when not deliberately taught. Journal of Pragmatics , 22, 157-167.

[7] Boxer, D., \& Pickering, L. (1995). Problems in the presentation of speech acts in ELT materials: The case of complaints. ELT Journal, 49, 44-58.

[8] Doughty, C. (2003). Instructed SLA: Constraints, compensation, and enhancement. In C. Doughty \& M. H. Long (Eds.), Handbook of second language acquisition. Oxford: Blackwell Publishing.

[9] Eslami-Rasekh, Z., Eslami-Rasekh, A., \& Fatahi, A. (2004). The effect of explicit metalinguistic instruction on the speech act awareness of advanced EFL students. TESL-EJ 8(2), 1-12.

[10] Fukuya, Y.J., Reeve, M., Gisi, J., Christianson, M., (1998). Does focus on form work for teaching sociopragmatics? 12th International Conference on Pragmatics and Language Learning, University of Illinois at Urbana-Champaign.

[11] House, J., (1996). Developing pragmatic fluency in English as a foreign language: Routines and metapragmatic awareness. Studies in Second Language Acquisition.18, 225-252.

[12] Jiang, X. (2006). Suggestions: What should ESL students know? System, 34, 36-54.

[13] Kasper, G. (1996a). Introduction: Interlanguage pragmatics in SLA. Studies in Second Language Acquisition, 18, 145-148.

[14] Kasper, G. (1996b). Developmental issues in interlanguage pragmatics. Studies in Second Language Acquisition, (18), $149-169$.

[15] Kasper, G. (1997). Can pragmatic competence be taught? Second Language Teaching \& Curriculum Center. Honolulu: University of Hawaii.

[16] Kasper, G. (2001). Classroom research in interlanguage pragmatics. In K. Rose \& G. Kasper (Eds.), Pragmatics in language teaching (pp. 33-60). Cambridge: Cambridge University Press.

[17] Kasper, G., Rose, K.R. (2002). Pragmatic development in a second language. A Supplement to Language Learning, 52, (suppl. 1). Blackwell, Mahwah, NJ

[18] Koester, A. J. (2002). The performance of speech acts in workplace conversations and the teaching of communicative functions. System 30, 167-184.

[19] Koike, D., (1989). Pragmatic competence and adult L2 acquisition: speech acts and interlanguage. Modern Language Journal 73 (3), 279-289.

[20] Koike, D. (1995). Transfer of pragmatic competence and suggestions in Spanish foreign language learning. In: S. Gass, \& J. Neu (Eds.), Speech Acts across Cultures (pp. 257-281). Mouton de Gruyter, Berlin.

[21] Koike, D., \& Pearson, L. (2005). The effect of instruction and feedback in the development of pragmatic competence. System, $33,481-501$.

[22] Kondo, S. (2001). Instructional effects on pragmatic development: refusal by Japanese EFL learners. Publications of Akenohoshi Women's Junior College 19, 33-51.

[23] Kondo, S. (2004). Raising pragmatic awareness in the EFL context. Sophia Junior College Faculty Bulletin, $24,4972$.

[24] Kubota, M. (1995). Teachability of conversational implicature to Japanese EFL learners. The Institute for Research in Language Teaching Bulletin 9, 35-67.

[25] Leowen, S. (2005). Incidental focus on form and second language learning. Studies in Second Language Acquisition, 27, 361386.

[26] LePair, R. (1996). Spanish request strategies: a cross-cultural analysis from an intercultural perspective. Language Sciences 18 (3-4), 651-670.

[27] Liddicoat, A. J., \& Crozet, C. (2001). Acquiring French interactional norms through instruction. In: K. R. Rose \& G. Kasper (Eds.), Pragmatics in Language Teaching (pp. 125-144). Cambridge: Cambridge University Press.

[28] LoCastro, V. (2000). Evidence of accommodation to L2 pragmatic norms in peer review tasks of Japanese learners of English. JALT Journal. 23, (1), 6-30.

[29] Long, M. (1991). Focus on form: a design feature in language teaching methodology. In R. Coste \& C. Kramsch (Eds.), Foreign language research in cross-cultural perspectives (pp. 39-52). Amsterdam: John Benjamin.

[30] Lyster, R. (1994). The effect of functional-analytic teaching on aspects of French immersion students' sociolinguistic competence. Applied Linguistics 15(3), 263-287.

[31] Martínez-Flor, A., Usó, E., Fernández, A. (Eds.). (2003). Pragmatic competence and foreign language teaching. Castellón: Servei de Publicacions de la Universitat Jaume I.

[32] McCarthy, M. J. (1998). Spoken language and applied linguistics. Cambridge: Cambridge University Press.

[33] Mir, M. (1992). Do we all apologize the same? - An empirical study on the act of apologizing by Spanish speakers learning 
English. Pragmatics and Language Learning 3, 1-19.

[34] Norris, J., \& Ortega, L. (2000). Effectiveness of L2 instruction: a research synthesis and quantitative metaanalysis. Language Learning 50(3), 417-528.

[35] Olshtain, E., \& Cohen. A. D. (1990). The learning of complex speech act behavior. TESL Canada Journal, 7, 45-65.

[36] Pearson, E. (1986). Agreement/disagreement: an example of results of discourse analysis applied to the oral English classroom. International Review of Applied Linguistics 74, 47-61.

[37] Rose, K. R., \& Kasper, G. (Eds.). (2001). Pragmatics in language teaching. Cambridge: Cambridge University Press.

[38] Rose, K. R., \& Ng, K. C. (2001). Inductive and deductive teaching of compliments and compliment responses. In K. R. Rose, \& G. Kasper (Eds.), Pragmatics in language teaching (pp. 145-170). Cambridge: Cambridge University Press.

[39] Safont, M. P. (2003). Instructional effects on the use of request acts modification devices by EFL learners. In A. Martinez-Flor, E. Uso, \& A. Fernandez, A. (Eds.), Pragmatic competence and foreign language teaching (pp. 211-232). Castellon, Spain: Servei de Publicacions de la Universitat Jaume I.

[40] Safont, M. P. (2004). An analysis on EAP learners' pragmatic production: a focus on request forms. Ibérica 8, 23-39.

[41] Safont, M. P. (2005). Third language learners: Pragmatic production and awareness. Clevedon, UK: Multilingual Matters.

[42] Salazar, P. C. (2003). Pragmatic instruction in the EFL context. In Martinez-Flor, A., Uso, E., Fernandez, A. (Eds.), Pragmatic competence and foreign language teaching (pp. 233-246). Castellon, Spain: Servei de Publicacions de la Universitat Jaume I.

[43] Schmidt, R. W. (1993). Consciousness, learning, and interlanguage pragmatics. In G. Kasper \& S. Blum-Kulka (Eds.), Interlanguage pragmatics (pp. 21-42). Oxford: Oxford University Press.

[44] Scotton, C. M., \& Bernsten, J. (1988). Natural conversations as a model for textbook dialogue. Applied Linguistics 9(4), 372384.

[45] Stalnaker, R. C. (1972). Pragmatics. In D. Davidson \& G. Harman (Eds.), Semantics of natural language (pp. 380-397). Dordrecht: Reidel.

[46] Takahashi, S. (2001). The role of input enhancement in developing pragmatic competence. In K. R. Rose \& G. Kasper (Eds.), Pragmatics in language teaching (pp. 171-199). Cambridge: Cambridge University Press.

[47] Tateyama, Y. (2001). Explicit and implicit teaching of pragmatic routines. In K. R. Rose, \& G. Kasper (Eds.), Pragmatics in language teaching (pp. 200-222). Cambridge: Cambridge University Press.

[48] Tateyama, Y., Kasper, G., Mui, L.P., Tay, H., Thananart, O., (1997). Explicit and implicit teaching of Japanese pragmatics routines. In: Bouton, L. (Ed.), Pragmatics and Language Learning (Vol. 8, pp. 163-177). University of Illinois: UrbanaChampaign.

[49] Tolli, A. P. \& Schmidt, A. M. (2008). The role of feedback, causal attributions, and self-efficacy in goal revision. Journal of Applied Psychology, 93, 692-701.

[50] Trosborg, A. (2003). The teaching of business pragmatics. In Martinez-Flor, A., Uso, E., Fernandez, A. (Eds.), Pragmatic competence and foreign language teaching (pp. 247-281). Castellon, Spain: Servei de Publicacions de la Universitat Jaume I.

[51] Wildner-Bassett, M. (1994). Intercultural pragmatics and proficiency: 'Polite' noises for cultural appropriateness. International Review of Applied Linguistics 32(1), 5-17.

[52] Wishnoff, R. J. (2000). Hedging your bets: L2 learners' acquisition of pragmatic devices in academic writing and computermediated discourse. Second Language Studies 19, 119-157.

[53] Yoshimi, D.R. (2001). Explicit instruction and JFL learner's use of interactional discourse markers. In: Rose, K.R., Kasper, G. (Eds.), Pragmatics in Language Teaching (pp. 223-244). Cambridge University Press, Cambridge.

Azin Salemi received her B.A. in translation and M.A. in teaching English as a foreign language (TEFL). Her areas of interest are second language acquisition, teaching skills, and pragmatics.

Mitra Rabiee holds a Ph.D. in TEFL from Islamic Azad University, Science \& Research Campus in Iran. She is currently an assistant professor in English Dept. at IAU \& has been teaching English since 1992. She has presented almost twenty papers in National \& International seminars \& conferences and published a couple of articles in different ELT journals. Her major academic interests include SLA issues, ELT methodology, and psycholinguistics.

Saeed Ketabi has a Ph.D in Applied Linguistics from the University of Cambridge, England and is currently teaching various ELT courses in the Faculty of Foreign Languages of the University of Isfahan and Islamic Azad University, Shahreza Branch. 